\title{
Prosper Mérimée, Plays on Hispanic Themes
}

\section{Scott Carpenter}

\section{(2) OpenEdition}

\section{Journals}

\section{Édition électronique}

URL : http://journals.openedition.org/studifrancesi/34902

DOI : 10.4000/studifrancesi.34902

ISSN : 2427-5856

\section{Éditeur}

Rosenberg \& Sellier

\section{Édition imprimée}

Date de publication : 1 novembre 2005

Pagination : 432s

ISSN : 0039-2944

\section{Référence électronique}

Scott Carpenter, «Prosper Mérimée, Plays on Hispanic Themes », Studi Francesi [En ligne], 146 (XLIX I

II) | 2005, mis en ligne le 30 novembre 2015, consulté le 18 avril 2021. URL : http://

journals.openedition.org/studifrancesi/34902 ; DOI : https://doi.org/10.4000/studifrancesi.34902

Ce document a été généré automatiquement le 18 avril 2021.

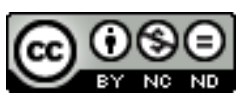

Studi Francesi è distribuita con Licenza Creative Commons Attribuzione - Non commerciale - Non opere derivate 4.0 Internazionale. 


\title{
Prosper Mérimée, Plays on Hispanic Themes
}

\author{
Scott Carpenter
}

\section{RÉFÉRENCE}

PROSPER MÉRIMÉE, Plays on Hispanic Themes, traduction et introduction d'OSCAR MANDEL, New York, Peter Lang Publishing, 2003, pp. 208.

1 L'ouvrage d'Oscar Mandel est une curiosité: outre une longue et élogieuse introduction, Plays on Hispanic Themes est un recueil de traductions de cinq pièces de Mérimée, dont certaines n'ont jamais été jouées, même du vivant de l'auteur. Portant les diverses casquettes de traducteur, de commentateur et de critique, Mandel se propose de mettre à la disposition du public anglophone des textes largement inconnus en France. Qui plus est il s'efforce de fournir toutes les indications nécessaires pour en faciliter la mise en scène.

2 Il aura du grain à moudre, car, comme il l'indique dans son introduction, même les spécialistes de Mérimée sont peu friands de ces ouvrages - que leur auteur même semblait considérer comme voués aux oubliettes de l'histoire littéraire. Or Mandel ne lâche pas prise, démontrant avec force exemples les innovations de Mérimée par rapport au théâtre de son époque. Devançant le théâtre romantique de Hugo, évitant les intrigues surchargées des mélodrames à la Pixérécourt, Mérimée aurait façonné un théâtre économe mais efficace, qui jouit de la même précision que ses contes et nouvelles. Mandel suggère que l'innovation même de Mérimée, en avance sur son temps, l'a mis en porte-à-faux avec le public. Si cette thèse peine à convaincre, ce ne sera pas faute d'effort de la part de Mandel: son introduction est moins un travail critique qu'une apologie en faveur du couronnement posthume d'un dramaturge délaissé par l'histoire.

3 Les pièces en question sont La Famille de Carvajal, Le Carrosse du Saint-Sacrement, L'Occasion, Inès Mendo et Inès Mendo ou le préjugé vaincu. Le premier titre fut publié en 
1828 avec La Jaquerie, alors que les autres parurent dans le recueil du Théâtre de Clara Gazul (1830). Mandel s'avère un traducteur compétent ses notes explicatives rendent les textes accessibles au lecteur moderne. On peut regretter certaines libertés prises avec les textes (telle la suppression de bon nombre d'indications scéniques), ce qu'il dit avoir fait dans le souci de rendre les pièces plus compatibles avec les besoins du théâtre moderne.

4 Moins un ouvrage critique qu'un manuel à l'intention des metteurs en scène, Plays on Hispanic Themes n'est pas près de déclencher une relecture générale des pièces de Mérimée. Mais Mandel rend un réel service en mettant ces textes à la disposition du public anglophone - d'autant plus qu'une pièce comme La Famille de Carvajal est en rupture de stock même en français - et ce depuis longtemps! 